\title{
Sean O'Faoláin, The Bell and the voice of Irish dissent
}

\author{
Colm McAuliffe
}

Department of English, UCC

\section{Introduction}

In October 1940, The Bell magazine was launched in Dublin under the editorship of Sean O'Faoláin. 'Whoever you are', declared O'Faoláin in his initial editorial, 'Gentile or Jew, Protestant or Catholic, priest or layman, Big House or Small House - The Bell is yours'. These words rang true throughout O'Faoláin's tenure at the helm of this influential periodical and ensured he was at the centre of the national dialogue concering Ireland's identity. My research will identify and examine how his highly politicised - and often censored editorials served as the springboard for an exploration of the collective malaise of a burgeoning yet often stunted post-revolutionary society.

\section{A most debatable state of flux}

Ireland of the 1940s is often maligned as a cultural wasteland, isolated politically and artistically as the war against Fascism raged elsewhere. As the new Ireland attempted to define itself, Seamus Deane remarked upon the era in rather bleak tones: 'Ireland ceased to be a mythological centre and became a provincial backwater'. However, this view is something of an exaggeration. In The Emergency (1978), Bernard Share remarks that these years of isolation did show some signs of cultural and intellectual vitality and were marked by a rising agitation against the country's ruthless censorship policy. O'Faoláin himself had raised the ire of the Censorship Board in 1936 when his novel Bird Alone was banned and, in response to this, he made it his business to launch consistent attacks on the board, considering their mentality to contravene revolutionary aims to be a sign of 'nationalism-in-decay'.

This research focuses on The Bell magazine, as it was the ideal platform for O'Faoláin to launch his principled opposition to the attitudes represented by the unremitting wave of censorship and to open the eyes of the public to the world beyond Ireland, a world in which the country's future was to lie. To achieve the latter, he had to focus his countrymen on the current state of their own country and O'Faoláin's 'spikily infuriating common sense' came to the fore in his editorials, as he repeatedly exasperated the pro-censorship 
lobby. He asserted that the board was completely out of touch with Irish cultural appetites, pointing to a large amount of respected writers who had fallen foul of the board's blinkered vision. These appetites, O'Faoláin believed were 'in the most debatable state of flux.'

A number of articles and pieces, originally published by O'Faoláin in the pages of The Bell — such as The Tailor and Ansty - were homages to a rural Irish tradition consisting of earthy language and 'innocent laughter' which again proved too much for the Censorship Board. These conflicts represented a public battle waged by an 'official' Ireland against what it left outside itself. My research will investigate how O'Faoláin, through the pages of The Bell, encouraged both his readers and his writers to appreciate the idea of the local or rural as part of an international viewpoint; the traditional Irish world is both preserved and criticised in its pages.

\section{The crucial role of the periodical}

O'Faoláin's biographer Maurice Harmon once opined that 'to make a complete bibliography of almost any Irish writer or to get a proper understanding of contemporary issues at any particular period it is necessary to examine the relevant periodicals...in pointing to a rich source of information that is frequently ignored...' Indeed, the study of periodical literature is sadly neglected. However, these magazines, particularly from the early 1940s onwards, trace a series of important events and innovations which lie just below the surface of Irish society and ultimately contain the seeds of the more dramatic changes in Ireland which were to occur in later decades.

As far back as 1971, Richard M. Kain, invoking George Moore, referred to the periodical genre as an 'untilled field'. One of the defining characteristics of periodical literature is that it serves as an initial training ground for upcoming writers, a resource for more established writers to experiment and as a forum to expound upon the burning issues of the day. In fact, The Bell itself in particular is a vital account, teeming with satires, sketches, advertisements, letters, all creating a constant and passionate dialogue about 1940s Ireland.

With O'Faoláin as editor, each issue of The Bell produced a unique sense of cohesion amongst disparate groups of individuals, linked together through a collective sense of identity which also offered a focus with which to interpret the world. Gerry Smyth remarks that '.. the essay, the editorial, the work-in-progress and the review are present-orientated discourses... They are discursive in the sense that they are recognisable interventions in on-going debates.'

This research into The Bell will demonstrate how it became one of the defining literary and cultural magazines of its era, particularly due to O'Faoláin adapting a heavy social and literary responsibility. The magazine was a refuge for forward-thinking writers, thwarted 
by the burden of anti-intellectualism in Ireland itself, with the likes of Brendan Behan, John Montague, Michael McLaverty and James Plunkett all benefiting from publication in the magazine at an early stage in their careers.

\section{Sean O'Faoláin: cultural theorist}

Research into Sean O'Faoláin is a similarly underdeveloped field and I intend to rectify this by reading O'Faoláin as a cultural theorist. Pre-emtping the dawn of cultural studies, O'Faoláin demonstrated his clear sense of the transformative potential of culture and of the written word as a refreshing contrast to the suffocating influence of the Irish State which insisted upon national inflexibility and closure.

O'Faoláin and The Bell laid the groundwork for a period when the analysis of culture within society was to become a crucial aspect of intellectual debate. In this instance, O’Faoláin's interests were shared with the cultural theory espoused by Raymond Williams, whose studies served as a major outlet for socio-political inquiry and criticism. Terry Eagleton could just as well have been speaking about O'Faoláin when he remarked that Williams' pioneering work 'insisted that culture meant not just eminent works of art, but a whole way of life in common; and culture in this sense included language, inheritance, identity and religion'.

As the Ireland of the twenty-first century recoils from a period of immense upheaval, our need for cultural commentators such a Sean O'Faoláin is more profound than ever. This research will posit O'Faoláin as a man who was both self-consciously Irish and an Irishman of the world, and as a vital figure in Ireland's intellectual development as a nation.

I would like to thank his supervisors Professor Graham Allen and Dr. Éibhear Walshe, School of English, UCC. 